\title{
EAST AND WEST
}

\author{
by \\ dr. Ada Bruhn Hoffmeyer
}

\section{Mutual Contributions to Civilization}

WEAPONS have always been an important factor in the civilization of man since the early days of prehistoric time. Primitive implements, combinations of weapons and tools, from the very early palaeolithic caves and abris, are known to us in several places of Europe and the Orient, particularly from the later parts of the Glacial Age and from the Post Glacial Age. From Aurignacien, Solutréen, Magdalénien and later epochs we have not only implements, but even the most impressive engravings and paintings on the rocky walls of the caves and abris in Italy, Alpine districts, Southern France and Northern Spain representing various kinds of animals such as bison, boar, horse, ibex and elephant. From Post Glacial time - covering a space from about $10.000-4.000$ B. C.-we find representations of man hunting animals with his weapons, particularly bows and arrows. These pictures of hunters are known from numerous abris, in Eastern and Southern Spain, the desert of Sahara, the mountains of Atlas, and in Southern Libya in a zone strechting just to the Red Sea. Even small sculptures or carvings in bone from somewhere between $20.000-10.000$ B. C., representing men hunting animals are known, for instance from Dordogne.

Stone implements and weapons made of flint, obsidian and local rock give evidence of man and his equipment at the coasts of the Mediterranean basin, in the Orient and in Europe as well as in other corners of the world. Various shapes and types of axes, spear-heads, arrow-heads, daggers and knives have been found, primitive in distant epochs and also later in some parts of the world, well-made, refined and polished in other parts of human civilizations. The progresses of human skill, and the evolution of cultural phenomena in the different branches of life can be read from archaeological objects, not least from the weapons. Folkmovements, trade relations, social conditions, daily life - to some extent even religious matters, though only in weak and uncertain traces - have been brought into light, thanks to such objects, their finding places, finding circumstances and their mutual relations.

The first knowledge of metal, the mining and the extraction of metals arose in the Orient, at some place in the neighbourhood of the Caucasian mountains, the slopes of the Taurus mountains, at the 
southern banks of the Black Sea, in all Anatolia in Asia Minor. From the eastern end of the Mediterranean basin it found its way particularly, by means of trade and exchange, via Mesopotamia, Asia Minor, Syria, Cypros, Egypt to the Aegean world, and from here to the middle and western parts of the Mediterranean, to Sicily, South Italy, the Iberian peninsula, though here it may have arisen independently, because of the rich occurrence of metals such as copper and particularly tin. Along the eastern coast of the Iberian peninsula it found its way to the Balearians, the Riviera coast and the western coast of Northern Italy. The existence of gold mines in Ireland was one of the causes of the establishment of some interchange between this far away island and the Iberian peninsula. From Asia Minor, across the Hellespont through Thrace, via the Danubian Valley and by way of the river Danube the knowledge was brought to Midland Europe, and by the rivers Elbe, Moldau and others it arrived at the coasts of the Baltic and even came to the North.

Copper, and soon afterwards bronze, was in use all over the Mediterranean world and in the Orient already in the last centuries of the third millenium B. C. Daggers and halberds, and soon after whole swords, were spread over the civilized world and were brought by trade - for instance in exchange of amber - from the southern world to the primitive tribes outside the civilized world. Weapons indicate the routes taken by progressing civilization from East to West and in northern directions. The sword and the axe are as important guides to the students of prehistoric archaeology as for instance fibulae and pottery, or as burial rites. The archaeological objects - and not least weapons - tell the students of to-day about trade-routes, folks' movements, daily life, social conditions, wars and peaceful existence. Often these objects behave like a pictorial puzzle. The results may be problematic, new excavations, new finds, enlarged knowledge and experiences may raise new theories, may change former results, establish them, certify or reject, but still the archaeological objects and not least weapons and their evolution. give many important hints about the life and civilizations of our forefathers in Orient and Occident.

In more advanced communities the archaeology of weapons may teach us something about military organization, tactics, about classifications of for instance cavalry, charioteers, infantry and the like. The combination of the single details of armament, the types and shapes of arms, their decoration and material tell something about local populations, foreign influence, invasions, folks' movements, warlike conquests etc. 
During a great part of antiquity currents from more advanced civilizations of the East went, not only along the shores of the Mediterranean, but even by ways of rivers to Midland Europe, to Western Europe and went from here across the Atlantic Ocean to the British Isles. But currents from the Aegean civilizations and and from Midland Europe flowed towards the East too, though not so abundant and strong as were the waves, which came from the East.

Not only during prehistoric time, but even in the historic periods of antiquity we find the same phenomena. Remember for instance the Persian wars with Classical Greece, or Greek colonization in Crimea and South Russia. With the campaign of Alexander Magnus and during the reign of the Hellenistic kings in Macedonia, Pergamon and Egypt, the Greek Hellenistic civilization spread to the Orient, penetrated the Eastern world as far away as to India. Even contacts established with China were a fact. Modern recherches, made as teamwork by Chinese, English and American scientists, who possess an intimate knowledge of the ancient Chinese sources, have brought into light such contacts - commercial and cultural for instance between the Far East and the Mediterranean civilizations of Greece and Rome, and later on with the Byzantine and Arab world. Mutual influences, interchanges of civilizations took place. The Roman empire adopted many elements and ideas from the Orient and yielded in return much to the Oriental world. The archaeology of weapons testifies to it, the art of war and its development, the changes in tactics and armament during Roman time bear witness to the mutual influences. The currents of civilization are reflected in shapes and types, in methods, organization and tactics. Mechanics, technical skill, style of decoration on swords and protective arms give excellent records of such an interaction. The Gladius Hispaniensis, a creation of the Celt-Iberians, based upon Celtic and Mediterranean influences, found its way - thanks to its superior quality of tempered blades, and thanks to its practical and effective shape - to the Roman legionary armies. With the expansion of the Roman empire this type of sword for a very long period went its triumphal way, to all the fields where Roman armies fought, where Roman military quarters were established, as far as Roman trade reached, in Western Europe, in Northern Europe, and far into the Orient. Greek, Roman and Oriental authors and historians from Herodotus to Ammianus and Procopios and many others, made the basis upon which later time authors and scientists up to Middle Ages and to the Renaissance built their handbooks on the art of war. The Roman time handbooks, such as for instance 
Polybios, Cæsar, Vitruvius, Vegetius and many others built upon experiences from battles with barbarous tribes and with the peoples of the Orient, and they combined their knowledge with theoretical ideas, though still sticking hard to old Roman organization and tradition. The foreign tribes, Oriental as well as Occidental and Northern, serving as mercenaries in the Roman armies, influenced the organization, tactics and armament. The peoples from Iran and from Bosporan areas meant quite a lot to the development of weapons and warfare in Europe, particularly in the later days of the Roman empire. To the foundation of medieval Europe the influence from peoples of the Orient played an important role. The Sarmate and Alane influence, with the Germanic Goths as intermediaries, contributed to the fall of South European infantry. Combined Roman and Barbarian armies had adopted important elements from the Orient, where their horsemen with bow and lance and the long cutand-thrust sword met the equally armed Huns of Attila in the Catalonian fields. The rise of cavalry in the Frankish armies slowly in Merovingian time, rapidly in Carolingian time, as we learn from the Capitularies of Charlemagne - rooted far back in Oriental influences brought to Europe already before the Great Migrations. And this influence was amongst others combined with the bad experiences in wars against the Magyar horsemen. The peoples of North Africa had already in antiquity a rapid light cavalry, such as the famous and rapid Numidian cavalry in the armies of Hannibal. When this cavalry was brought over to Spain during the campaign of Hannibal, the local populations, particularly the Celt-Iberians, learnt how to increase the rapidity of their own light cavalry. Later on, in early Middle Ages, when various Berber tribes crossed the Strait of Gibraltar, still new impulses gave rise to a renewal and to reorganizations of prior units of cavalry in Christian Spain. With the Berber tribes of the 11 th and 12 th centuries new types of cavalry swords and new methods of using them were introduced into Spain and later on into other parts of the Latin world.

The Byzantine empire, the wars of Justinianus, conducted by his excellent generals Belisar and Narses, against the Persians in the East, the Vandals in North Africa and the Goths of Italy, brought new impulses to Europe. Already the emperor Leo I (457-474) had taken warning from the fate of the West Roman empire. His successor Zeno (474-491) took up the military virtus of the semiromanized peoples of the mountains of Asia Minor, the Isaurians and the Armenians. He left an excellent army, half European, half Oriental, to his successor. The armies of Justinianus were composed 
of light Asiatic cavalry and heavy squadrons of Lombards, Herules and Gepides with their characteristical armaments.

The handbooks in the art of war by Maurikios, Leo, Nicephoros Phocas and others were of no small importance, though as regards medieval Europe the handbooks of the Roman authors, above all Vegetius, became almost like a Bible to authors and scientists in the art of war. (Greek language was almost unknown to the Western world in the Middle Ages outside some few monasteries in Sicily, South Italy, Spain, Ireland and Southern England). In the East, war had been scientifically studied as an art for centuries, and the Byzantine generals boasted of their skill in conquering Franks and Saracens, Slavs and Turks, using the same tactics and the same types of arms as the hostile nations they were fighting against. The invention of Greek fire, which made Byzantine artillery - particularly naval artillery - and later on the Arab artillery an important and dangerous instrument of war, became a stimulus to the evolution of artillery in Western Europe, specifically on account of the Arab literature about pyrotechnics and alchemy.

Through Byzantium and the Arabs the traditions of Hellenistic and Roman war-engines had been preserved, and the Occident received its knowledge about them from the Orient. The use of naphtha-pots in throwing engines were taken over from the Arabs.

The empire of Charlemagne had close contact with the Caliphate of Damascus and with the emperor of Byzantium. The interchange of embassadors in the 9 th century between the Moorish rulers in Córdoba and the Byzantine emperors is well-known. The military academy of the university of Córdoba had been an important source for the Castilian king Alfonso el Sabio, when in the 13th century he wrote his handbook in the art of war.

The Arabs, the most dangerous foes of the East Roman empire, had taken over much knowledge from Byzantium, and Classical traditions were preserved here from Hellenistic and Roman times. »They have copied the $» R h o m a i o i \ll$ in most of their military practices, in arms and in strategy", says the emperor Leo in his Tactica. And it was true. But they often practised it in their own manner. With the expansion of Islam, the traditions of antiquity were brought south of the Mediterranean to Egypt and via North Africa to Spain. By the partition of the Caliphate of Damascus in an Eastern one with its centre in this city, and a Western one with its centre in Córdoba, the traditions from antiquity expanded further. The university of Córdoba, the very first university in Europe, became a centre of learned studies, and it was frequented by students from all the civilized world. Hellenistic and Arab philosophy, histo- 
ry, poetry, sciences such as mathematics, astronomy, medicine were cultivated here. The ancient traditions were preserved and enlarged, and Moorish spiritual life became a most important pillar to the evolution of medieval spiritual life in Europe. North of the Mediterranean the stormy events of the Great Migrations had in many ways broken the links between Antiquity and dawning Middle Ages. Slowly a new civilization grew up, thanks to the expansion of Christianity and to the Universal Catholic Church. But round the Mediterranean the Byzantine empire, the Moslims with their learned men of Persia, Damascus, Alexandria, Córdoba had linked the two epochs together. Here the chains between the antique Classical world and the new era had not been broken in spite of wars, conquests, defeats and the like. The Arab literature about the art of war comprises for instance essays about cavalry, how to manage a cavalry lance, archery, pyrotechnics, the forging and tempering of sword blades etc., topics of great interest to students of European weapons and art of war.

In the Western world a feudal cavalry was established in the 11 th century. There was brought an end to the stage of experiment of the Dark Ages of Western and Central Europe. The Crusades naturally meant a lot to the evolution of cavalry and cavalry equipment. Just as the Arabs had taken over a good deal of their warfare and armament from the Byzantine empire, as Leo says, the European knighthood, coming to the metropolis of his empire, learned a lot during their stay in Byzantium, in Asia Minor and in Palestine, particularly concerning protective arms for man and horses, heraldry and fortresses. But from their hostile encounters with the Arab light cavalry, archery and tactical methods, their own besieging of cities and fortresses, more by prolonged starving technic than by use of artillery-engines, they learned remarkably little. Of course they brought back to Europe new impressions, new ideas, new types of weapons, such as for instance curved Turkish sabres, horseman's maces and other types of arms. But as a whole these new weapons got only little influence upon the European armament. Greek fire and the use of naphtha became of no great importance to European knighthood, though we hear about it now and then. The European architecture of fortresses and castles is indebted to Byzantium and to the Arabs. The encounter between, for instance, Richard Coeur de Lion and Saladdin, or the crusade of Saint Louis might have been more fertile to European art of war. It was chiefly the development of protective arms for man and horse which got inspiration from the Eastern heavy cavalry.

But not only from Byzantium, Persia and the Arab countries, new 
impulses penetrated the Occident. The movements of the Mongols of Central Asia, the Turkish and Tatar movements pressed upon the Eastern Caliphate. Still currents went from Asia to the Mediterranean and even to Midland Europe. The Turkish menace to the weak and disorganized Byzantine empire in the 14th century and particularly in the 15th century concluded in the Turkish siege of the metropolis and its fall in the year 1453, the first true instance of artillery as an important weapon in the art of siege. The constant Turkish menace had driven a great part of Greek speaking learned persons as fugitives to Italy, bringing Greek manuscripts, Greek language, Greek civilization to the important cities of Italy, the learned and rich noblemen of which received them with open arms. These Greek waves became one of the basic pillars upon which the young Renaissance built. Italian trade connexions with Egypt, Syriil, India and even China, brought new currents from the East to Southern Europe, at the same time as occidental currents flowed in eastern directions. The Aragonese power of Cataluña, its rulership, for instance, over Sicily, parts of Sardinia and the Balkans, the new Aragonese kingdom of Naples, where artists and craftsmen, learned persons and tradesmen from all the Mediterranean and eastern world met, the contacts, for instance of the Aragonese king Alfonso $\mathrm{V}$ of Naples with almost all countries around the Mediterranean, with Peking and with Ethiopia, and his imperialistic ideas resulted in a Renaissance, based upon the new interest of GrecoRoman antiquity and supported by the strong and many-sided influences from the East. A humanism became the result in the spiritual world, a Renaissance in the material world. Certainly the most important invention of the time was the art of printing. But the invention and particularly the improvement of gun-powder, a greater technical skill, the new science founded upon the basis of Moslim and ultimately the Hellenistic science, - completely changed the art of war. New weapons, a new organization, new tactics were the results. New handbooks of war, by Gonzalo de Córdoba and Machiavelli, though still to some extent based upon the antique Romans, such as Polybios, Cæsar and particularly Vegetius - just as regards Egidius in the 13th century with his handbook showed ideas and experiences of their own, combined with impulses from the East. Armament changed. The art of fencing brought new types of swords and rapiers. Artists and craftsmen were highly influenced by the decorative styles coming via Venezia from the Orient, brought by Oriental craftsmen and tradesmen. Benvenuto Cellini talks about this in his memoirs, giving a description of the Turkish daggers and their damascened goldornaments. 
And how much had not the Moorish civilization in Spain contributed? The Toledan blades, the particular Toledan damascening in gold and silver, known and still used in our days. The Toledan damascening soon became particularly popular in France.

Wars with the Turks, the naval battles at Tunis, at Lepanto and the Turkish sieges of Vienna brought other impulses to Europe, to the South, to the Midland and to the North.

Of importance were the Discoveries of the New World by Colón, the voyages of Vasco da Gama and Maghellan. These navigators contributed to the reinforcement of contacts for instance with China and the Far East and brought new currents to Europe. European types of weapons took over Oriental elements in shape and decoration just as in the East we find European types with Oriental decoration, or purely European objects. Even Far Eastern ancestorial figures are furnished with European weapons.

Still through the ages the civilization of the Occident is indebted to the civilizations of the Orient, just as the Orient is indebted to the Occident. All branches of human civilization were affected. But in the present papers the branches concerning arms and armaments, warfare and its contacts with human civilization should be the main objects to be considered. The history of arms and armour is an important branch of science, supporting the sciences of archaeology, history and art.

The interaction, the mutual influences from Occident and Orient are to be treated in these papers, with the Mediterranean world as the centre from which the rays are emitted to East and West, and where they cross and reflect. The review has been baptized GLADIUS, not only because it is the intention to treat the sword as well as other weapons and implements of war for hunting, ceremonies etc., but because the mutual interactions of civilizations - amicable as well as hostile - even figuratively, were brought with sword in hand. The glaive has been replaced by the plume in order to treat these interactions between Occident and Orient, and to throw light upon the ancient weapons as bearers of human civilization, not only as instruments of war.

The Oriental sources - for several reasons - are often inaccessible to most Europeans, possibly more inaccessible than the European sources are to the students from the Oriental countries. Therefore it is the intention to establish a kind of team work between students from the Occidental and the Oriental world, out of the desire to supplement the knowledge about the reciprocal actions, caused by weapons and their relations to human civilization in its many branches and fields. We cherish the hope of being able to issue a number of the review at least once a year. 